\title{
EFFECTS OF ANTI-GRAFFITI PROTECTION ON CONCRETE DURABILITY
}

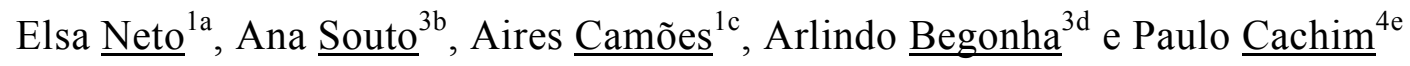 \\ 1: C-TAC, Departamento de Engenharia Civil, Universidade do Minho,4800-058 Guimarães, \\ Portugal
}

2: Departamento de Engenharia Civil, Universidade do Minho, 4800-058 Guimarães, Portugal

3: Faculdade de Engenharia, Universidade do Porto, Rua Dr. Roberto Frias, s/n, 4200-465 Porto, Portugal

4: Departamento de Engenharia Civil/Labest, Universidade de Aveiro, 3810-193 Aveiro, Portugal

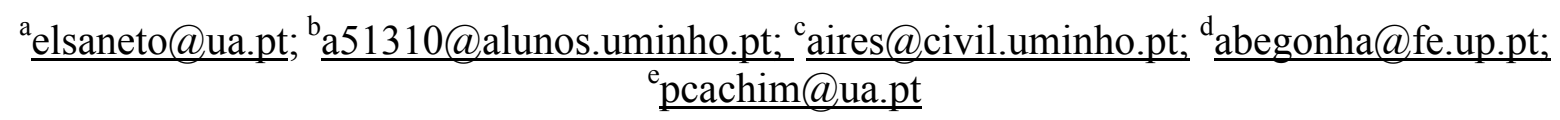

\begin{abstract}
The patrimony of fair-faced concrete, largely built in the twentieth century and nowadays recognized as heritage to be protected, is susceptible to attacks by graffiti, a form of vandalism that causes a major social and economic impact on society. The concrete is a porous material sometimes deteriorated over the years, and the interactions of the inks and the substrate and removal methods sometimes deteriorate or alter the concrete surface, especially if it is necessary to repeat the removal process. The anti-graffiti products are applied on the surface of the concrete, hindering the adhesion of paints or preventing its penetration into the pores of the concrete, which in turn facilitates their removal. However, it appears that many of the existing protective products on the market also alter the surface characteristics of the concrete irreversibly. Considering that the durability of concrete depends on the composition and characteristics of the surface, it is essential to know the effects of anti-graffiti protection systems on the durability of concrete and contribute to an appropriate methodology to preserve this heritage. Thus, an experimental program was developed for analyzing changes in durability indicators and surface properties that protect concrete from deterioration (i) concrete without protection before and after application of spray paint, (ii) concrete with protection before and after application of spray paint and (iii) after paint removal were studied. Two antigraffiti products were evaluated: a permanent and a sacrificial one. Effects of the anti-graffiti systems on the concrete durability are investigated and the tests performed include: water absorption by capillary and immersion at atmospheric pressure. The results of the water absorption tests show that the graffiti protection reduces the water absorption into the concrete and facilitates the removal of the graffiti without affecting the characteristics of the surface and thus contributing to improve its durability.
\end{abstract}

Key-words: heritage, preservation, anti-graffiti protection, durability.

\section{INTRODUCTION}

The graffiti phenomenon has grown in recent years and is currently an enormous economic and social problem. The pleasure degrading, the breaking of the interdict and defy the authorities are roughly the determinants of life graffiter [1]. In any country, there is patrimony subjected to the aggressive style of graffiti. In Europe there are over 3,500,000 protected monuments affected despite the preventive measures that are being implemented [2]. Patrimony in exposed concrete is susceptible to attacks by graffiti, which are particularly aggressive to porous surfaces. Apparent concrete is a design option in works of art, in public and private buildings and public buildings 
coverings, constituting a remarkable heritage that must be properly protected from these acts of vandalism.

Graffiti can be executed with various materials, but about eighty percent are applied in the form of painting with spray paint or felt markers on large walls, bridge pillars, subways, roads, parks and often in historical heritage [3]. In addition to the aesthetic aspect, the interaction of the paint with the concrete surface and the paint removal methods used, which are based on the application of chemicals or physical/mechanical methods, do not always result in the complete removal of graffiti $[4,5]$. Often, they can alter or cause serious damage to the deeper layers of the substrate, especially if it is necessary to continuously repeat the process of removing and the repair of the damages involves high costs. When the removal is carried out with a chemical, in many cases, stains appear on the concrete resulting from the solvent penetration and the modification of the substrate (Fig.1). The deterioration process occurs at the level of the concrete pores. The paints are absorbed through the pores of the concrete, making the removal process difficult. Removal by a mechanical process yields micro cracks on the concrete surface providing a means of entry of aggressive ions.

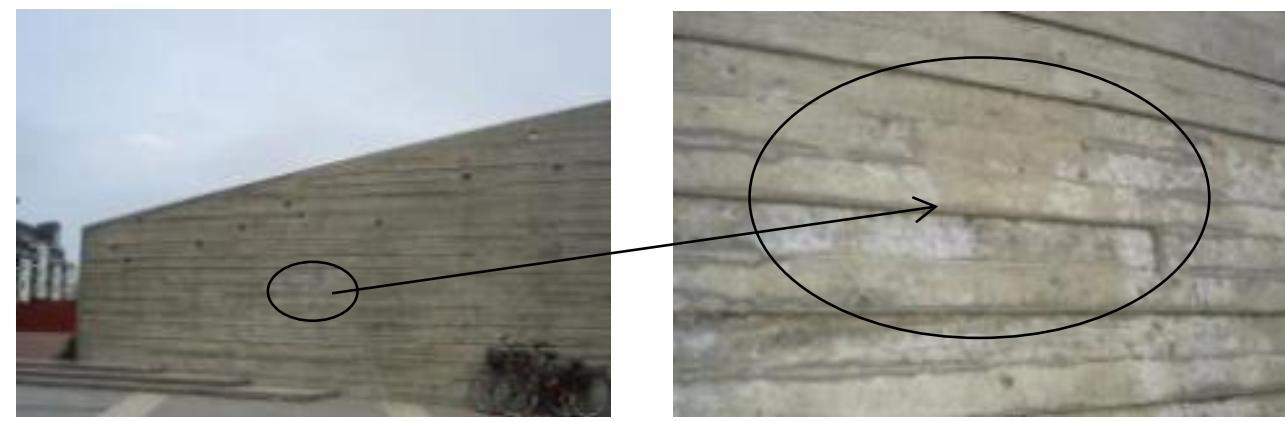

Figure 1- Exposed concrete after removal of graffiti, Malmö, Sweden (2011)

In order to prevent such assaults, products for protection against anti-graffiti have been developed to form a protective barrier against vandalism, by lowering the surface energy of the substrate and becoming water and oil repellent. Therefore, paints adherence is hindered, facilitating their removal or preventing their penetration into the pores of the substrate. In contrast, the protective coating must have good adhesion to the concrete surface and thus a high surface tension of the support relative to the protective coating anti-graffiti is necessary [6], [7]. When the concrete surface is treated with a water repellent product, the surface properties change from hydrophilic to hydrophobic; preventing the water droplets to penetrate into the concrete and the surface is just open to the diffusion of gases. Figure 2 illustrates the role of a surface treatment for water repellence, often referred to as the Lotus effect. The contact angle $\theta$, a quantitative measure of the wetting of a solid by a liquid, corresponds to the angle between a drop of liquid at the interface liquid/gas/solid.
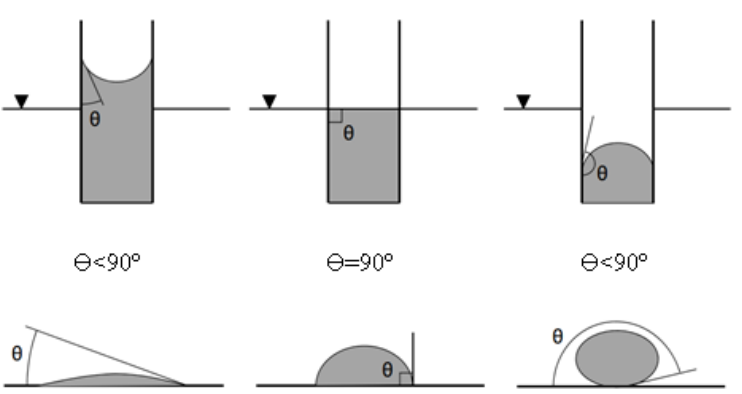

Figure 2 - Difference between a hydrophilic and a hydrophobic material considering the contact angle ( $\theta)$ : hydrophilic material $\left(\theta<90^{\circ}\right)$ and hydrophobic $\left(\theta>90^{\circ}\right)$ 
For a hydrophilic material such as concrete, it is often considered that the contact angle is zero [8]. The durability of concrete depends mainly on the composition and properties of the surface layer [9]; in particular the thickness of the reinforcement coating, which in most cases is responsible for protecting the equipment against corrosion. Concrete durability will be greater the lower will be its water absorption capacity, its carbonation degree and its permeability to chloride [10]. The control of the water inflow into the concrete surface is particularly important because, by not entering water, carbonation reaction does not occur, since carbon dioxide and chlorides only penetrate inside the concrete carried by the water. Due to its hydrophobic properties, products for the protection of graffiti can also temporarily protect the concrete from environmental actions, acting as a barrier between the environment and the concrete surface and preventing or delaying the entry of harmful substances [11]. Concrete can be simultaneously protected from graffiti vandalism and corrosion. To ensure effective protection of the concrete surface, protection products must still have high permeability to water vapor, low permeability to carbon dioxide and water, good adhesion to the substrate, good retention of properties on aging, good crack bridging ability and good resistance to alkalis [12], [13].

The protective anti-graffiti products can be classified into two groups with different chemical characteristics: (1) permanent, which remains on the surface after removing the ink and remains effective after several cycles of ink removal, being fluoralkylsiloxane-water-based systems especially effective in surfaces of porous materials such as concrete [14]; (2) sacrificial, generally waxes, is removed together with the ink with hot water above the wax melting point, being required further application so that the affected area remains protected. However, it turns out that these surface treatments are often applied without having a complete knowledge of the substrate properties or the optimal molecular structure recommended for the prevention may not have been chosen, leading to insufficient protection or degradation of the materials involved [15]. Therefore it is necessary to improve the current knowledge on the interaction between treatments for anti-graffiti protection and exposed concrete substrate and the effect of graffiti removal on the durability of exposed concrete and thus contribute to the establishment of a correct methodology of intervention and consequently get useful information on new products formulation.

In this sense, an experimental program was developed to analyze and compare the effect of two treatments for anti-graffiti protection, a permanent and a sacrificial, over conventional (CONV) and high-performance (HPC) exposed concrete and evaluate parameters of durability in the following conditions: (i) concrete without protection before and after application of spray paint and (ii) concrete with protection before and after application of spray paint and (iii) after paint removal. Anti-graffiti products, if properly used, can protect the concrete from graffiti attacks and simultaneously prolong the service life of the structure.

\section{EXPERIMENTAL PROGRAM}

\section{Concrete}

Table 1shows the detailed composition of conventional concrete (CONV) and high-performance concrete (HPC) that were produced in Central Betão Liz (CIMPOR group).

\begin{tabular}{|c|c|c|c|c|c|c|c|c|c|c|c|}
\hline \multirow[t]{2}{*}{ Concrete } & $\begin{array}{l}\text { Binder } \\
\text { (B) }\end{array}$ & Cement & $\mathrm{CV}$ & $\begin{array}{c}\text { Sand } \\
1\end{array}$ & $\begin{array}{c}\text { Sand } \\
2\end{array}$ & $\begin{array}{c}\text { Course } \\
\text { Aggregate } \\
1\end{array}$ & $\begin{array}{c}\text { Course } \\
\text { Aggregate } \\
2\end{array}$ & $\begin{array}{l}\text { Water } \\
\text { (w) }\end{array}$ & Plast. & SP & \multirow[t]{2}{*}{$\mathrm{W} / \mathrm{B}$} \\
\hline & {$[\mathrm{kg}]$} & {$[\mathrm{kg}]$} & [kg] & {$[\mathrm{kg}]$} & {$[\mathrm{kg}]$} & {$[\mathrm{kg}]$} & {$[\mathrm{kg}]$} & {$[\mathrm{A}]$} & {$[\mathrm{kg}]$} & {$[\mathrm{kg}]$} & \\
\hline CONV & 320 & 210 & 110 & 320 & 590 & 520 & 480 & 150 & 1,92 & 2,56 & 0,52 \\
\hline HPC & 480 & 340 & 140 & 230 & 430 & 600 & 510 & 154 & 2,88 & 3,84 & 0,36 \\
\hline
\end{tabular}


For each concrete composition, several specimens were prepared: cubic with $150 \mathrm{~mm}$ edge and cylindrical with $100 \mathrm{~mm}$ diameter and $200 \mathrm{~mm}$ height. After demolding, the specimens were kept immersed in water for 28 days at controlled temperature $\left(21^{\circ} \mathrm{C}\right)$.

\section{Paint of graffiti}

The simulation was performed with black graffiti spray paint (Ironlak product), usually used by the graffiters. It is an acrylic fast drying paint with high opacity gloss and very pigmented. Contain: butyl glycol, acetone, ethyl acetate, butyl acetate and titanium dioxide. Paint was sprayed with $45^{\circ}$ slop and $15 \mathrm{~cm}$ distance from the surface of the specimens. This paint is favorable to the execution of graffiti painting over large areas due its fast drying and complete fixation to the porous support, being the color black the most commonly used. Figure 3 shows the elemental composition of this paint obtained by Scanning Electron Microscopy with X-ray microanalysis (SEM-EDS).

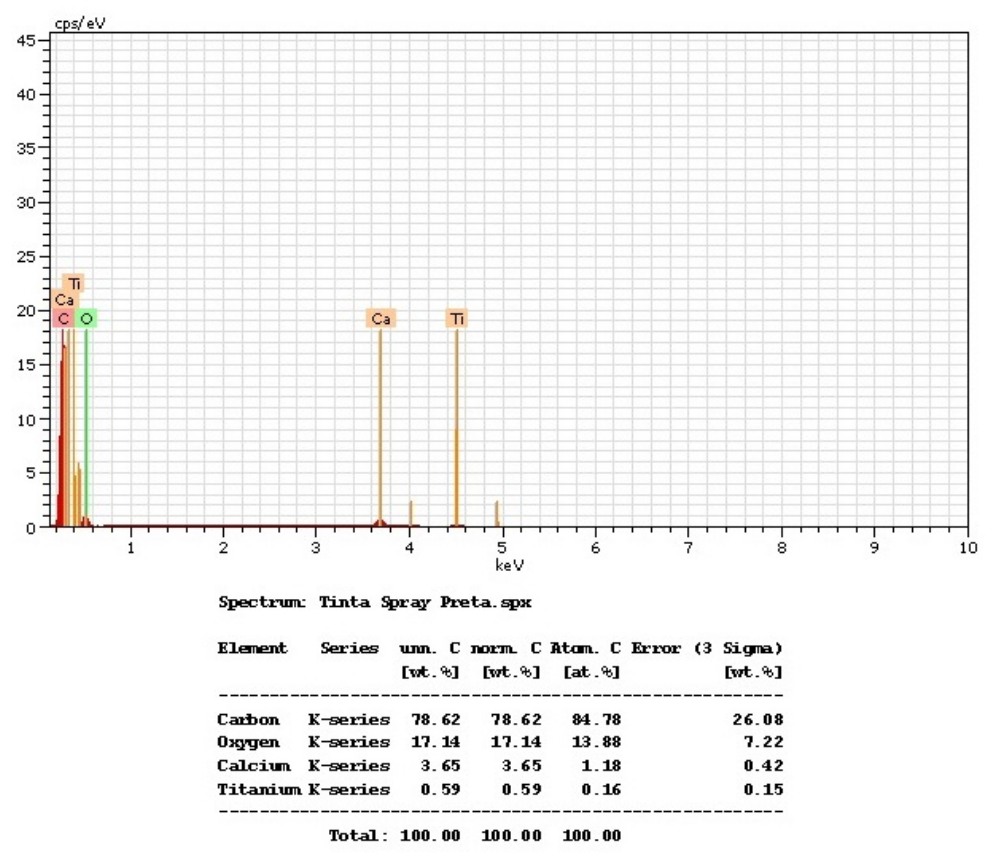

Figure 3. Spray paint analysis by SEM-EDS

\section{Anti-graffiti systems}

We analyzed several products available on the market, but it was found that the concrete surface was practically unaltered after application of two products. Therefore, these two anti-graffiti systems, with different chemical characteristics, were considered for the experiment: a permanent system $\left(\mathrm{AGS}_{1}\right)$ and a sacrificial system $\left(\mathrm{AGS}_{2}\right)$, both listed as products for the protection of porous materials and practically free of volatile solid compounds (specified in each product data sheet).

The $\mathrm{AGS}_{1}$ is a water-based fluoralkylsiloxane system, with light yellow color, with density 1.06 and $\mathrm{pH}$ 4. This product is suitable for modifying the surface properties of porous materials, such as concrete, lowering their surface energy and thus making the surface water/oil repellent, the removal of the paint being performed with a chemical. The product pick-up on the concrete surface is about 120 to $200 \mathrm{~g} / \mathrm{m}^{2}$, per coating. The application proceeds as follows: first, a primary product (a waterbased hydrophobic solution) is directly applied onto the concrete surface, and, after $24 \mathrm{~h}$ of drying, three coatings of the anti-graffiti product are applied (with intervals between coatings of 2 hours). However, the surface only acquires the full protective effect after $72 \mathrm{~h}$. According to the datasheet, this product supports 10 cycles of graffiti paint removal. A cleaning product is used to remove the paint being applied in a circular motion for 20 minutes without allowing its drying; then the surface 
is washed with water at a maximum pressure of 12 bar (Fig. 4). As seen in Figure 4, the spray paint does not easily adhere to the concrete surface with the permanent protection AGS1 due to its oleoand hydrophobic properties.

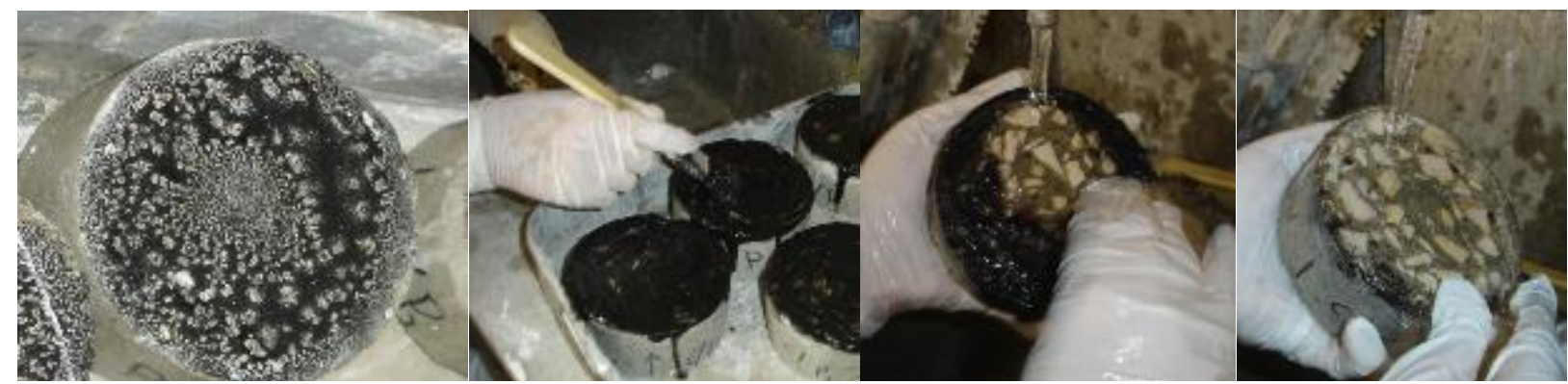

Figure 4 - Removal process of spray paint from the concrete surface protected with $A G S_{1}$

The $\mathrm{AGS}_{2}$ is a white water-based wax dispersion containing $10-15 \%$ of active wax, slightly more viscous than water, with density 1 and $\mathrm{pH} 8-9$, and a melting point of $80-85{ }^{\circ} \mathrm{C}$. The paint removal is carried out with only hot water. The product pick-up on the concrete surface is about 120 to $150 \mathrm{~g} / \mathrm{m}^{2}$, per coating. It is applied directly on the concrete surface in three coatings using a brush, with drying intervals of 2 hours. According to the data sheet, the surface is protected from water and resistant to graffiti within 4 hours after application of the last coating. However, the surface only acquires the full protective effect after $72 \mathrm{~h}$. This product, in addition to its protective properties to graffiti is characterized by providing protection against moisture and pollution penetration on the concrete surface, still being permeable to water vapor. The paint removal is carried out by projecting of hot water $\left(90^{\circ} \mathrm{C}\right)$ at $90-110$ bars. After the graffiti removal, in order to keep the surface protected, a new application of the product in the affected area is mandatory. In Figure 5, it can be seen that the spray paint forms a continuous film on the concrete surface protected with $\mathrm{AGS}_{2}$. Furthermore, the ink is simultaneously removed with the protection product, which is the reason why a new application of the sacrificial product is required. For each protection system, the respective procedure was performed for both types of concretes tested.

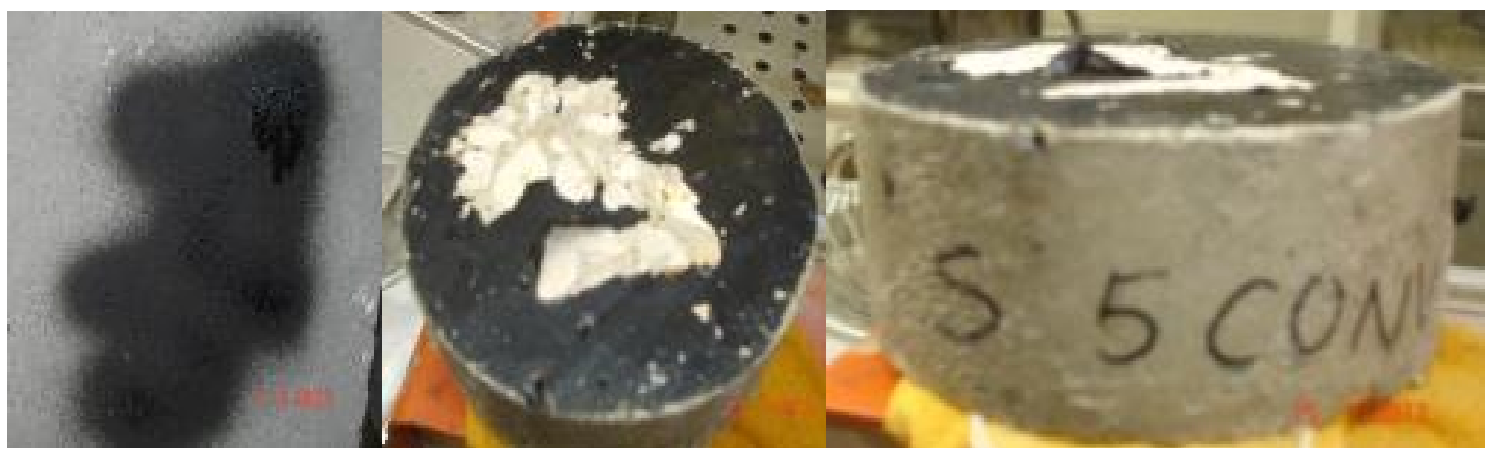

Figure 5 - Removal process of spray paint concrete surface with sacrificial protection $A G S_{2}$

The anti-graffiti product penetrates the concrete pores mainly by capillary absorption. In the case that the concrete pores are filled with water then the force of the capillary absorption is negligible, which means that, under these conditions, it is difficult to achieve an acceptable degree of product penetration. The ratio $\mathrm{W} / \mathrm{B}$ is a parameter of porosity and as such, the structure of conventional concrete $(\mathrm{W} / \mathrm{B}=0.52)$ ought to be more porous than the one of high-performance concrete $(\mathrm{W} / \mathrm{B}=$ 0.36). Therefore, it is expected that the penetration of the product is more difficult in the case of HPC. 


\section{Experimental procedure}

The tests, carried out at the Laboratory of Building Materials of University of Minho, aim the characterization of the main properties of the concrete related to deterioration mechanisms, i.e., to evaluate the effect of (1) the two protection treatments against graffiti paint and (2) the graffiti paint and its removal, on the concrete durability.

At first, tests were performed to characterize the behavior of the two concrete mixtures CONV and HPC, workability of fresh concrete (NP EN 12350-2 [16]) and compressive strength (EN 12390-3 NP [17] - on 3 cubic concrete specimens 150x150x150 $\mathrm{mm}^{3}$ aged 7, 14, 28 and 90 days). Then, the indicators of concrete durability [18] were analyzed on both concretes considering its anti-graffiti protection with $\mathrm{AGS}_{1}$ or $\mathrm{AGS}_{2}$ systems, according to the previously described conditions: i) concrete without anti-graffiti protection before $(\mathrm{W} / \mathrm{P})$ and after the spray paint application $(\mathrm{W} / \mathrm{P}+\mathrm{G})$; ii) concrete with anti-graffiti protection before $(\mathrm{P})$ and after applying the spray paint $(\mathrm{P}+\mathrm{G})$ and iii) concrete after the paint removal $(\mathrm{P}+\mathrm{G}+\mathrm{R})$. The tests performed were: water absorption by capillarity (LNEC E393 [19]), on 3 cylinder specimens with $100 \mathrm{~mm}$ in diameter and $200 \mathrm{~mm}$ in height (Ø100 x 200), and water absorption by immersion at atmospheric pressure (LNEC E394 [20]), on 3 cubic specimens with 150x150x150 $\mathrm{mm}^{3}$.

\section{EXPERIMENTAL RESULTS AND DISCUSSION}

\section{Concrete}

Fresh state

The behavior of concrete in the fresh state was performed according to NP EN 12350-2 [16] Table 2.

Table 2 - Workability of concrete

\begin{tabular}{|c|c|}
\hline Concrete & Slump [mm] \\
\hline CONV & 130 \\
\hline HPC & 190 \\
\hline
\end{tabular}

\section{Hardened concrete}

Compressive strength test of the concrete compositions was performed according to EN 12390-3 NP [17] of specimens aged of 7, 14, 28 and 90 days and the results are shown in Figure 6. The HPC at 7 days reached a compressive strength about $85 \%$ higher than the conventional concrete, the 90 day compressive strength of HPC amounted to $72.2 \mathrm{MPa}$ and, at the same age, the conventional concrete had a compressive strength of $49.3 \mathrm{MPa}$.

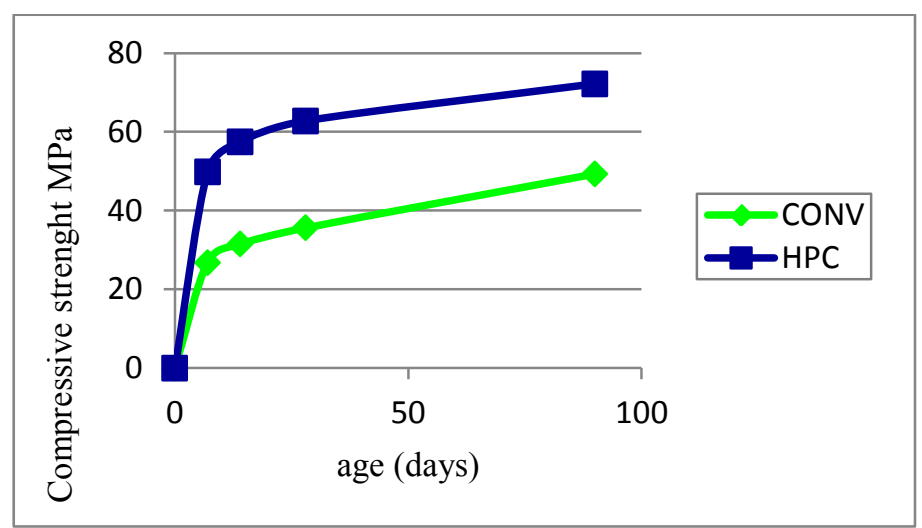

Figure 6 - Compressive strength test results over time 


\section{Water absorption by capillarity}

The sorptivity coefficients obtained from water absorption by capillary action for CONV and HPC (Fig.7) without the graffiti protection and with the protection $\mathrm{AGS}_{1}$ and $\mathrm{AGS}_{2}$ are shown in Table 3 and Figure 8 . These tests allowed registering the respective capillary absorption kinetics, expressed by the ratio between the mass of water absorbed per unit area as a function of square root of time. The capillary absorption coefficients were determined from these curves and using the method of least squares, considering only the first 7 hours of the test. Approaches have revealed to be appropriate; this statement is the fact that the respective linear correlation coefficients, $\mathrm{R}^{2}$, have reached very high, greater than $94.7 \%$.

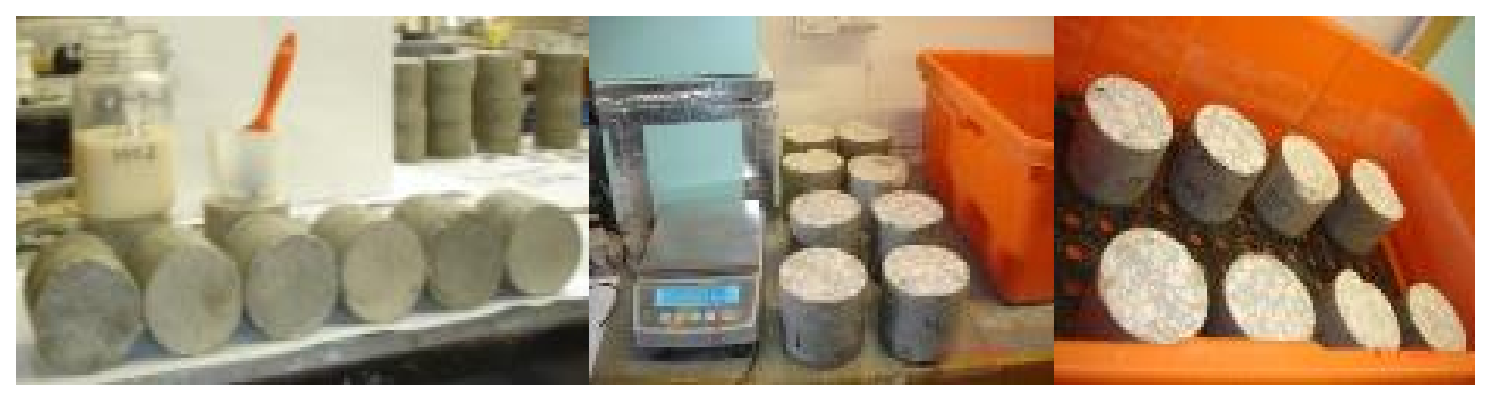

Figure 7-Procedures of water absorption by capillarity test

Table 3 - Values of absorption by capillarity $\left[\mathrm{kg} /\left(\mathrm{m}^{2} \cdot \mathrm{h}^{0,5}\right)\right]$

\begin{tabular}{|c|c|c|c|c|c|c|c|c|}
\hline \multirow{3}{*}{ Concrete } & \multirow{2}{*}{\multicolumn{2}{|c|}{ Concrete without antigraffiti protection }} & \multicolumn{6}{|c|}{ Concrete with antigraffiti protection } \\
\hline & & & \multicolumn{3}{|c|}{ Permanent $\mathrm{AGS}_{1}$} & \multicolumn{3}{|c|}{ Sacrificial $\mathrm{AGS}_{2}$} \\
\hline & $\mathrm{W} / \mathrm{P}$ & $\mathrm{W} / \mathrm{P}+\mathrm{G}$ & $\mathrm{P}$ & $\mathrm{P}+\mathrm{G}$ & $\mathrm{P}+\mathrm{G}+\mathrm{R}$ & $\mathrm{P}$ & $\mathrm{P}+\mathrm{G}$ & $\mathrm{P}+\mathrm{G}+\mathrm{R}$ \\
\hline CONV & 3,67 & 1,82 & 1,74 & 1,13 & 1,84 & 0,960 & 0,799 & 2,40 \\
\hline $\mathrm{HPC}$ & 3,19 & 1,29 & 1,20 & 0.785 & 1,53 & 0,799 & 0,701 & 1,57 \\
\hline
\end{tabular}

Figure 8 shows the unprotected graffiti concrete, the value of water absorption by capillarity on CONV was higher than on HPC, although in the initial period (30 min) present slightly below. After applying the spray paint, there is a decrease of water absorption for both concretes, keeping the amount of water absorption of CONV higher than of HPC.

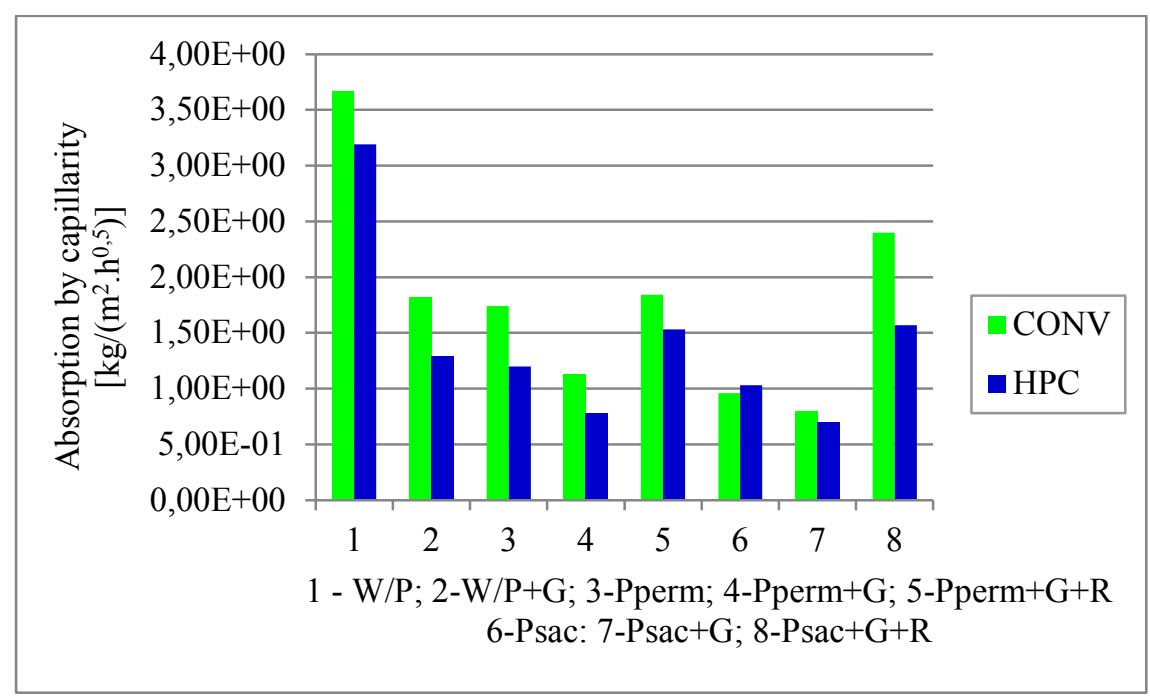

Figure 8 - Water absorption by capillarity test results 
In the case of protected concrete, the values of capillary absorption for CONV with permanent protection are slightly higher than those observed for CONV with sacrificial protection, whereas for HPC, these values are very close for both permanent and sacrificial protection. In the case of protected concrete with spray paint, capillary absorption decreased for both CONV and HPC either with permanent and sacrificial protection, although in the initial period $(60 \mathrm{~min})$ values were somewhat higher and the values for the specimens with sacrificial protection are lower compared to those observed with permanent protection.

After removing the spray paint, CONV and HPC showed higher capillary absorption; these values being even higher than those originally obtained for concrete protection before applying the paint, more significantly for the CONV with sacrificial protection. It is important to note that the capillary coefficients after paint removal come close to the reference values (concrete without protection) especially in the case with the sacrificial protection, but still significantly lower. These results suggest that the removal operation does not degrade the surface.

\section{Water absorption by immersion}

Table 4 gives the values obtained in the test of water absorption by immersion for CONV and HPC, without the graffiti protection and with the protection $\mathrm{AGS}_{1}$ and $\mathrm{AGS}_{2}$.

Table 4 - Coefficients of Water absorption by immersion $A_{\text {im }}[\%]$

\begin{tabular}{|c|c|c|c|c|c|c|c|c|}
\hline & \multirow{2}{*}{$\begin{array}{c}\text { Concrete without anti- } \\
\text { graffiti protection }\end{array}$} & \multicolumn{5}{|c|}{ Concrete with anti-graffiti protection } \\
\cline { 5 - 9 } Concrete & $\mathrm{W} / \mathrm{P}$ & $\mathrm{W} / \mathrm{P}+\mathrm{G}$ & $\mathrm{P}$ & $\mathrm{P}+\mathrm{G}$ & $\mathrm{P}+\mathrm{G}+\mathrm{R}$ & $\mathrm{P}$ & $\mathrm{P}+\mathrm{G}$ & $\mathrm{P}+\mathrm{G}+\mathrm{R}$ \\
\hline $\mathrm{CONV}$ & 11,9 & 12,0 & 8,0 & 11,6 & 7,2 & 7,3 & 10,4 & 6,8 \\
\hline $\mathrm{HPC}$ & 10,7 & 11,5 & 7,2 & 9,4 & 7,2 & 6,4 & 10,0 & 6,2 \\
\hline
\end{tabular}

In the unprotected concrete, water absorption by immersion is slightly higher for CONV compared to HPC, keeping this trend after applying the spray paint. After applying the protection onto the concrete, water absorption by immersion decreased about $3-4 \%$ for both concrete (CONV and HPC), compared to the concrete without protection; in addition, the water absorption of both concretes with sacrificial protection is smaller than with the permanent protection. In CONV and HPC with protection and with spray paint, with both types of protection, there is an increase in water absorption, reaching values close those of the concrete without protection (Fig.9).

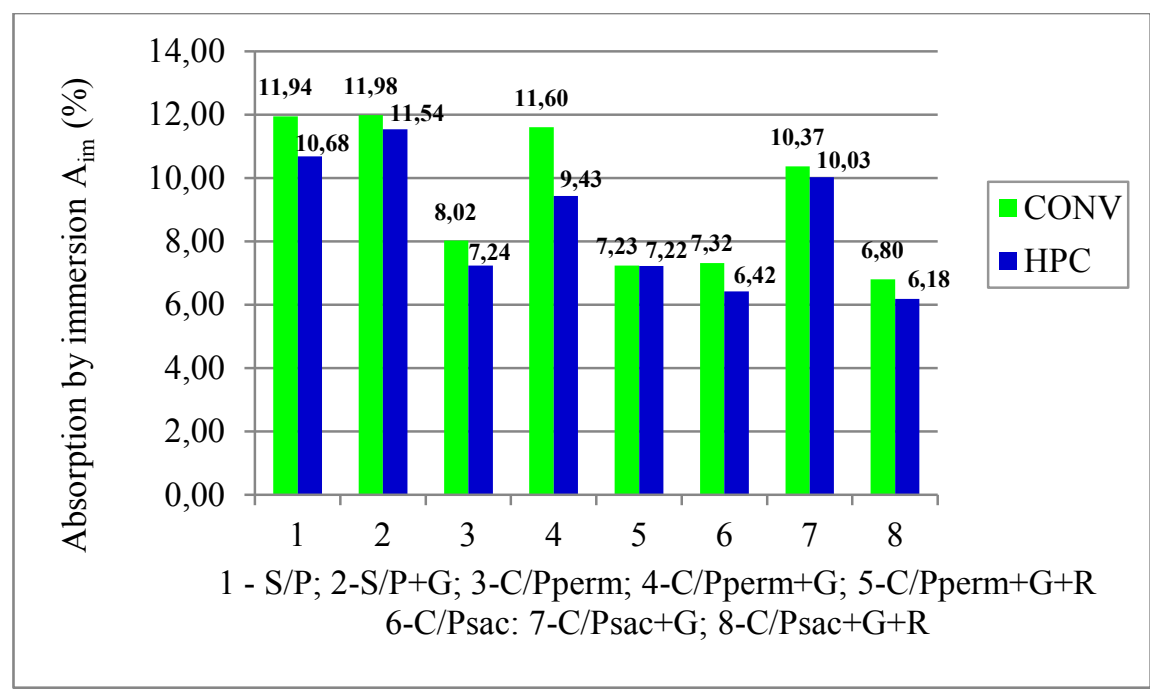

Figure 9 - Water absorption by immersion test results 
After the paint removal, for both concretes and for both types of protection, water absorption is similar to the initial situation of concrete with only protection. The fact that water absorption by immersion increases for concrete with protection and with paint may be due to the paint characteristics, and therefore studies should be performed to confirm if water retention occurs on the concrete surface after graffiti painting.

\section{CONCLUSIONS}

The tests results allow to assess that:

- The application of spray paint on the concrete surface, CONV and HPC, significantly decreases water absorption by capillarity comparing with unprotected concrete; on the other hand;

- Regarding water absorption by immersion, it was found that after the application of spray paint on both protected concrete surface, CONV and HPC, there was a significant increase, reaching almost identical values to those observed for the unprotected concrete. The occurrence of this situation may be due to the spray paint characteristics and may cause water retention on the concrete surface;

- Anti-graffiti protection decreases the capillary water absorption into the concrete; this capillarity being greater the greater concrete porosity. $\mathrm{CONV}$ has a greater tendency to capillary absorb water than HPC, since CONV structure (W/B $=0.52)$ is more porous than HPC's $(\mathrm{W} / \mathrm{B}=0.36)$;

- Anti-graffiti protection also decreases water absorption by immersion in CONV and HPC, being this behavior similar for both anti-graffiti protection products;

- The values water capillary absorption for CONV and HPC before applying the spray paint and after paint removal are identical in the case of concrete with permanent protection $\left(\mathrm{AGS}_{1}\right)$, while the concrete with sacrificial protection $\left(\mathrm{AGS}_{2}\right)$ reaches values close to the unprotected concrete.

The anti-graffiti products protect from water ingress inside concrete and allow easy removal of graffiti without changing the surface properties; an improved performance being observed when using the permanent protection. Graffiti paint also decreases water absorption into the unprotected concrete. However, the application spray paint on protected concrete appears to increase water retention on concrete surface, situation that should be analyzed.

\section{REFERENCES}

1. Levisohn, Cedar. Street Art. Tate Publishing. Eds. 2009.

2. Lozano, J.Sebastián. Catálogos nacionales de património de Europa: una visión en conjunto, II Jornadas Europeas de Património Cultural, Madrid, 2001.

3. Matsui, I, Onda, A., Shinozaki, S., Kyo, E., Nagai, K., Yuasa, N. Method of Removing Graffiti from the Surface of Concrete. Key Engineering Materials. Vols 302-303 (2006). pp 363-370.

4. Garcia,O., Rodrigez-Maribona,I., Laschewsky,A., Dworak,A., Hoffmann., Vanhellemont,Y., Giavarini,C., Strupi Suput,J., Boron,H., Revilla,M.P. and Brea,B. (2006). Development of a new antigraffiti system, based on tradicional concepts, preventing damage of architectural heritage. Proceedings of the $7^{\text {th }}$ Conference "SAUVEURS". SAFEGUARDED CULTURAL HERITAGE. Understanding \&Viability for the Enlarged Europe. Prague, Czech Republic, (2006), pag.111-115.

5. Carmona-Quiroga, P., Martinez-Ramirez, S., Sobrados, I. \& Blanco-Varela, M.. Interaction between two anti-graffiti treatments and cement mortar (paste). Cement and Concrete Research 40 (2010), pp. 723-730.

6. Resende, João Alexandre (2010). Análise dos efeitos de produtos preventivos e corretivos antigraffiti no granito do Porto (2010).

7. Saidi, Salima et Geribaldi, Serge (2001). Polymères contre graffiti. L'ACTUALITÉ QUE. Mars (3) 2001, p3-14. 
8. Johanssonn, A., Janz, M., Silfwerbrand, J. \& Trägårdh, J. Moisture Diffusion Coefficient of Impregnated Concrete, Proceedings, Hydrophobe IV $-4^{\text {th }}$ International Conference on Water Repellent Treatment of Building Materials, Stockholm, Sweden, April 12-13, Aedificatio Publishers (2005), pp79-90.

9. Kreijger, P.C. (1984). The skin of the concrete. Composition and properties.Materials and Structures, 17275-283.

10. Basheer L, Kroop J and Cleland DJ 2001. Assessment of the durability of concrete from its permeation properties: a review. Construction and Building Materials, vol. 15, $\mathrm{n}^{\circ}$ 2-3, pp. 93 103.

11. Swamy, R. N., Suryavanshi, A. K. and Tanikawa, S. Protective ability of an acrylic-based surface coating system against chloride and carbonation penetration into concrete. ACI Materials Journal 95 (1998), 101-112.

12. Hammer, Tor Arne and Plesser, Thale Sofie Wester. Effect of surface treatment on chloride ingress and carbonation in concrete structures-State of the art. COIN Project report 3 (2008).

13. Stadelmann,V.F. Acrylic and styrene/acrylic polymers. Handbook of coatings for concrete. Whittles Publishing. (2002). Caithness, pp.21-34.

14. Standke, B., Jenkner, P.K., Sorger, R. (1999). Easy-to-clean and Anti-Graffiti Surfaces: New Invisible Coatings on Porous Mineral, with Fluoralkylsilane Systems.Degussa-Huls AG, Germany.

15. Carmona-Quiroga, P., Martinez-Ramirez, S., Sobrados, I. \& Blanco-Varela, M. (2010). Interaction between two anti-graffiti treatments and cement mortar (paste). Cement and Concrete Research 40 (2010), pp723-730.

16. NP EN 12350-2.2009, Ensaios do betão fresco - Parte 2:ensaio de abaixamento.Lisboa:IPQ.11p.

17. NP EN 12390-3.2009, Ensaios do betão endurecido-Parte 6:resistência à compressão de provetes.Lisboa:IPQ.21p.

18. Camões, Aires and Costeira, André (2012).Durabilidade de Betões Reforçados com Fibras de Aço. BE-2012-Encontro Nacional de Betão Estrutural. Porto - 24, 25 e 26 de Outubro de 2012.

19. LNEC E393.1993, Concrete. Determination of the Absorption of Water Through Capillarity. Lisbon, $2 p$.

20. LNEC E394.1993, Concrete. Determination of the Absorption of Water by Immersion. Atmospheric pressure test. Lisbon, $2 \mathrm{p}$.

21. RILEM TC.154-EMC.2003, Electrochemical techniques for measuring metallic corrosion half-cell potential measurements-potential mapping on reinforced concrete structures. Materials Structures, vol. 36, p.p.461-471.

22. LNEC E463.2004, Determinação do coeficiente de difusão dos cloretos por ensaio de migração em regime não estacionário. Lisbon, $7 p$.

23. LNEC E391.1993, Betões-Determinação da resistência à carbonatação.

24. Fpr CEN /TS 12390-12. Testing hardened concrete - Part 12: Determination of the potential carbonation resistance of concrete: Accelerated carbonation method. 